\title{
Propranolol for infantile haemangiomas: a review
}

\author{
E Starkey, H Shahidullah
}

Derbyshire Children's Hospital, Derby, UK

\section{Correspondence to} E Starkey, Derbyshire Children's Hospital, Uttoxeter Road, Derby DE22 3NE, UK; elizabeth.starkey@nhs.net

Accepted 16 April 2011 Published Online First 28 May 2011

\begin{abstract}
Infantile haemangiomas are the most common benign tumour of infancy. However the majority are selfresolving and only a small minority of cases require treatment, with various different medications being used in the past. Over the last few years, propranolol, a non-selective $\beta$-blocker, has become a popular and successful treatment for infantile haemangiomas. However, further research on its safety is needed if it is going to be used more frequently. This article summarises the current literature on propranolol for haemangioma treatment with emphasis on its toxicity and adverse event profile.
\end{abstract}

\section{INTRODUCTION}

Infantile haemangiomas are commonly seen in paediatrics with a small number being a challenge to manage. Over the last few years, propranolol has become increasingly popular as a successful medication choice with fewer side effects than other current treatments. At present propranolol is awaiting licensing by the European Medicines Agency for use for haemangiomas but is licensed for other paediatric conditions. If it is to be used more frequently for haemangioma management, then its efficacy and safety profile must be investigated in more depth. It is important when any drug is used for a new indication that those who are not familiar with prescribing it understand the potential adverse effects. This article aims to review the evidence on propranolol therapy for infantile haemangiomas with a particular focus on its safety profile.

Articles were found through a literature search using MedLine and EMBASE. MeSH terms used included 'haemangiomas' and 'propranolol' and the subheadings 'drug therapy', 'toxicity' and 'adverse events'.

\section{EPIDEMIOLOGY AND NATURAL HISTORY}

Infantile haemangiomas are the most common benign tumours in infancy affecting $5-10 \%$ of the population. ${ }^{1}$ They are seen less commonly in African American and Asian compared to Caucasian children and occur more frequently in females with a female:male ratio of $3: 1 .^{2}$ The head and neck region is the most frequently involved area $(60 \%)$, followed by the trunk (25\%) and the extremities $(15 \%){ }^{3}$

Infantile haemangiomas have a predictable natural history. The majority are not present at birth. However, a minority may have a precursor lesion such as a vascular patch or area of pallor. Soon after birth infantile haemangiomas undergo significant growth (proliferative phase) for several months followed by gradual involution which usually occurs over several years. Regression is complete in $50 \%$ of 5 -year-old patients and $90 \%$ of 9-year-old patients. ${ }^{4}$

The majority of children with infantile haemangiomas require no treatment as the lesions regress over time and produce no long term scarring. In approximately $10 \%$ of cases, depending on their anatomical site, there can be serious or life threatening complications requiring treatment (see table 1). ${ }^{5}$ At present there are no gold standard systemic treatments for infantile haemangioma. The current approach for complicated infantile haemangiomas includes the use of systemic or intralesional corticosteroids, chemotherapeutic agents such as $\alpha$ interferon and vincristine, laser therapy, surgical resection or a combination of these treatments. ${ }^{6}$ At present there are no published comparative studies of these approaches.

\section{PROPRANOLOL AND INFANTILE HAEMANGIOMAS}

In 2008, a child with obstructive hypertrophic cardiomyopathy was treated with propranolol at $3 \mathrm{mg} / \mathrm{kg} / \mathrm{day}$. This child was noted to have a co-existing nasal haemangioma and there was a coincidental improvement of the haemangioma while the child was on propranolol. The same authors studied a series of 11 patients and found a significant change in both the colour and softness of haemangiomas within the first $24 \mathrm{~h}$ on propranolol, with all haemangiomas improving. ${ }^{7}$ Subsequently, numerous other case reports and small studies have been undertaken showing promising results as seen in table 2 . The age range for starting propranolol varies in the literature ${ }^{6-17}$ Current evidence shows more predictable shrinkage of the tissue with propranolol, but unlike other treatments propranolol also has an effect on the tissue once the involution phase commences. ${ }^{7}$

\section{PHARMACOKINETICS}

Individual $\beta$-blockers vary with regard to their $\beta$ receptor selectivity, intrinsic stimulatory activity, lipid solubility and membrane-stabilising (sodium channel) effects. Stimulation of $\beta_{1}$ receptors increases inotropy, chronotropy and automaticity in the heart, while $\beta_{2}$ receptor stimulation results in bronchodilatation and enhanced gluconeogenesis. ${ }^{18}$

At present in the UK, propranolol is licensed in children for use in migraine prophylaxis, arrhythmias, thyrotoxicosis and tetralogy of Fallot. ${ }^{19}$ It is a non-selective $\beta$-adrenergic antagonist that demonstrates equal affinity for both $\beta_{1}$ and $\beta_{2}$ receptors and therefore acts on multiple tissues. The use of propranolol has been well studied in adults and when taken orally it shows significant first pass metabolism with peak absorption within 1-3 h and a half life of around 3.5-6 h. ${ }^{20}$ There are no 
published pharmacokinetic studies on propranolol in infants or children.

\section{MECHANISM OF ACTION}

Haemangiomas are composed a number of cell types including endothelial cells. Recent studies have found that capillary endothelial cells express $\beta_{2}$ adrenergic receptors. ${ }^{21}$ Propranolol is thought to exert its effects on growing haemangiomas by three different molecular mechanisms: vasoconstriction, inhibition of angiogenesis and induction of apoptosis. ${ }^{20}$

The autonomic nervous system and epinephrine play key roles in the control of vascular tone. Epinephrine can cause both vasoconstriction and vasodilatation by activating both the $\alpha_{1}$ receptors and $\beta_{2}$ receptors, respectively. $\beta$-Blockers without $\alpha$-antagonistic effects like propranolol inhibit epinephrine mediated vasodilatation and this leads to vasoconstriction of endothelial cells. ${ }^{22}$

During the growth phase of haemangiomas, there is increased expression of two major proangogenic factors:

Table 1 Sites at high risk for complications of infantile haemangioma $^{5}$

\begin{tabular}{ll}
\hline Sites & Complications \\
\hline Head, neck, perineum, lip & Ulceration \\
Airway & Airway obstruction \\
Eye & Astigmatism, amblyopia, tear duct \\
& obstruction, proptosis, ptosis, strabismus \\
& and myopia \\
Lumbosacral region & Spinal dysraphism, tethered spinal cord \\
& and genitourinary anomalies \\
Liver & Hepatomegaly, congestive heart failure, \\
& thyroid abnormalities \\
\hline
\end{tabular}

basic fibroblast factor and vascular endothelial growth factor (VEGF). Recent publications have found that the expression of VEGF is reduced by $\beta$-blockers which thus leads to inhibition of angiogenesis. ${ }^{23}$

Apoptosis is regulated by a number of pathways, with the $\beta_{1}$ adrenoreceptor being the probable receptor involved. It has been hypothesised that by blocking the $\beta_{1}$ adrenoreceptor, propranolol induces apoptosis at an increased rate. ${ }^{24}$

\section{THERAPEUTICS}

Most groups have used a dose of $1-3 \mathrm{mg} / \mathrm{kg} / \mathrm{day}$ (table 2) for the treatment of infantile haemangiomas. However, the duration of treatment ranges widely from 3 to over 12 months. Some continue the medication until regression starts or there is complete haemangioma resolution. ${ }^{14}$ The majority perform baseline cardiology investigations prior to commencing propranolol in outpatients. ${ }^{6}{ }^{14}$ However, some are still cautious and admit their patients to hospital for heart rate and blood pressure monitoring. ${ }^{13}$ All the groups discussed their protocol with their local cardiology service; it is important to hold discussions with the relevant specialities involved in looking after such children. The current literature supports the tapering of propranolol at the end of the course over a 2-3-week period, ${ }^{6} 21$ presumably to prevent the known problem of rebound tachycardia. ${ }^{25}$

\section{OUTCOME}

Studies have shown that haemangioma relapse rates vary after propranolol is stopped (see table 2) with some studies showing no relapse, ${ }^{11-13}$ while others have reported that some minor changes reoccurred requiring some patients to restart propranolol. ${ }^{7}$ One study found that $47 \%$ of patients showed some

Table 2 Propranolol dosing, duration and outcome in infantile haemangiomas

\begin{tabular}{|c|c|c|c|c|c|c|c|}
\hline Author & Country of study & $\begin{array}{l}\text { Number of } \\
\text { patients }\end{array}$ & $\begin{array}{l}\text { Dose range } \\
\text { (mg/kg/day) }\end{array}$ & $\begin{array}{l}\text { Age range } \\
\text { (median, months) at } \\
\text { initiation (months) }\end{array}$ & $\begin{array}{l}\text { Location of } \\
\text { haemangioma }\end{array}$ & $\begin{array}{l}\text { Duration of } \\
\text { treatment } \\
\text { (months) }\end{array}$ & Outcome \\
\hline Buckmiller et $a /^{6}$ & USA & 41 & 2 & $1.5-30(7.1)$ & Multiple sites & Not reported & $\begin{array}{l}16 \text { excellent } \\
\text { responders } 15 \text { partial } \\
\text { responders1 non- } \\
\text { responder }\end{array}$ \\
\hline Leaute-Labreze et al $l^{7}$ & France & 11 & $2-3$ & $2-6(3.2)$ & $\begin{array}{l}\text { Facial: } 10 \\
\text { Forearm: } 1\end{array}$ & $4-12$ & $\begin{array}{l}\text { All regressed or } \\
\text { stabilised }\end{array}$ \\
\hline Sans et $a l^{8}$ & France & 32 & $2-3$ & $2-41(4.2)$ & Multiple sites & $3-10$ & $\begin{array}{l}10 \text { regressed } 6 \text { mild } \\
\text { relapse } 9 \text { treatment } \\
\text { ongoing }\end{array}$ \\
\hline Denoyelle et $a l^{9}$ & France & 2 & $2-3$ & 4 and 11 & $\begin{array}{l}\text { Phaces: } 1 \\
\text { Subglottic: } 1\end{array}$ & 7 & $\begin{array}{l}\text { Both responded with } \\
\text { no regression }\end{array}$ \\
\hline Rosbe et a/ ${ }^{10}$ & USA & 3 & $1-2$ & 3 weeks -8 months (4.9) & Subglottic & $7-18$ & $\begin{array}{l}2 \text { completely } \\
\text { responded }\end{array}$ \\
\hline Marsciani et al ${ }^{11}$ & Italy & 1 & $1-2$ & 2 & Hepatic & Not reported & Excellent response \\
\hline Li et $a l^{12}$ & Australia & 4 & 2 & 11 weeks-2.5 years $(10.5)$ & Orbital & $6-12$ months & All improved \\
\hline Manunza et $a l^{13}$ & UK & 30 & 2 & $1.2-13.5(5.8)$ & Facial & $3.5-15$ & All improved \\
\hline Haider et a $/^{14}$ & USA & 17 & $\begin{array}{l}\text { Initially } 0.5 \text {, } \\
\text { increased } \\
\text { slowly to } 2\end{array}$ & 3 weeks -12 months & Periocular & $\begin{array}{l}\text { Until resolution } \\
\text { or } 9-11 \text { months } \\
\text { of age }\end{array}$ & $\begin{array}{l}10 \text { excellent respond- } \\
\text { ers } 6 \text { good response } 1 \\
\text { fair response }\end{array}$ \\
\hline Maturo et al ${ }^{15}$ & USA & 2 & 2 & 3 and 5 & Airway & Not reported & Both responded \\
\hline Nauouri et a/16 & France & 4 & $1-2$ & 5 weeks -5 months $(3.0)$ & $\begin{array}{l}\text { UlceratedLip: } 1 \\
\text { Body: } 2 \\
\text { Skull: } 1\end{array}$ & $\begin{array}{l}92 \text { ongoing } \\
\text { treatment }\end{array}$ & $\begin{array}{l}3 \text { excellent } \\
\text { response1 relapsed } \\
\text { off treatment }\end{array}$ \\
\hline Qin et $a l^{17}$ & China & 58 & $1-1.5$ & $1-12(4)$ & Multiple & $2-5$ & $\begin{array}{l}10 \text { excellent } \\
\text { response } 35 \text { good } \\
\text { response12 moder- } \\
\text { ate response1 poor } \\
\text { response }\end{array}$ \\
\hline
\end{tabular}




\section{Box 1 Side effects of propranolo $\left.\right|^{8} 19$}

- Bradycardia

- Hypotension

- Bronchospasm

- Hypoglycaemia

- Peripheral vasoconstriction

- Gastrointestinal disturbances

- Behavioural changes/sleep disturbances

- Rashes - purpura, psoriatic type

- Profuse sweats

- Diarrhoea

success on propranolol but needed further therapy for resolution of the haemanagiomas. ${ }^{6}$ A minority of patients may not respond to propranolol treatment. ${ }^{617}$ Given that the majority of the literature is based on small numbers of patients, further research is needed to provide more accurate relapse and nonresponder rates. The methods for quantifying change in haemangiomas are also an area for further investigation.

\section{TOXICITY}

$\beta$-Blockers have a well documented safety and side effect profile. The common side effects are listed in box 1 . There has been one reported death in children related to $\beta$-antagonists. This followed ingestion of a significant overdose of propranolol by a 7-year-old girl. ${ }^{26} \mathrm{~A}$ further review revealed that in 40 years of clinical use at therapeutic doses in children less than 7 years of age, there have been no cases of mortality and no serious cardiovascular events. ${ }^{27}$

The most serious side effect of propranolol is hypoglycaemia, ${ }^{28}$ which has also been reported following its use for infantile haemangiomas. ${ }^{14} 2930$ Holland et al reviewed 21 cases of hypoglycaemia related to propranolol use. ${ }^{31}$ Eleven (52\%) patients were receiving long term treatment for over 5 months at doses ranging from 2 to $14 \mathrm{mg} / \mathrm{kg} / \mathrm{day}$. Some $94 \%$ of the episodes occurred after a period of fasting with the majority occurring in the early morning. There have been a few cases with low doses ( $<4 \mathrm{mg} / \mathrm{kg} /$ day) suggesting that the hypoglycaemia may not always be dose dependent. ${ }^{31}$ Propranolol is thought to cause hypoglycaemia by inhibiting glycogenolysis, gluconeogenesis and lipolysis. ${ }^{28}$ Children seem to be more susceptible to hypoglycaemia for two reasons. Firstly they have lower glycogen stores leading to reduced fasting ability and secondly they have higher glucose utilisation rates when fasting. ${ }^{31}$

Another concern is that $\beta$-blockers can mask the early sympathetic signs of hypoglycaemia such as tachycardia, sweating and palpitations. It is therefore advised that propranolol should be temporarily discontinued in those with reduced calorie intake or inter-current illness. ${ }^{28}$

A recent case report has also described an infant who developed hypoglycaemia after starting propranolol while on a tapering dose of corticosteroids. This suggests that there maybe an additional risk of hypoglycaemia secondary to adrenal suppression from long term steroid use. ${ }^{29}$ This may have implications for the treatment of infantile haemangiomas given that current practice is to use steroids as first line therapy in complicated haemangiomas.

There is limited evidence on the incidence of adverse events or drug reactions with $\beta$-blockers used within their clinical indication. A study reporting on paediatric $\beta$-blocker toxicity
Table 3 Side effects reported in infantile haemangioma studies

\begin{tabular}{|c|c|c|c|c|}
\hline Author & $\begin{array}{l}\text { Number of } \\
\text { patients }\end{array}$ & $\begin{array}{l}\text { Dose range } \\
\text { (mg/kg/day) }\end{array}$ & $\begin{array}{l}\text { Number of } \\
\text { side effects } \\
\text { reported }\end{array}$ & Side effects \\
\hline Buckmiller et $a /^{6}$ & 41 & 2 & 10 & $\begin{array}{l}\text { Somnolence: } 6 \\
\text { Gastro- } \\
\text { oesophageal } \\
\text { reflux: } 2 \\
\text { Allergic } \\
\text { reaction: } 1 \\
\text { RSV } \\
\text { exacerbation: } 1\end{array}$ \\
\hline Sans et $a l^{8}$ & 32 & $2-3$ & 9 & $\begin{array}{l}\text { Insomnia: } 2 \\
\text { Agitation: } 2 \\
\text { Nightmares: } 1 \\
\text { Profused } \\
\text { sweats: } 1 \\
\text { Asthma onset: } 1 \\
\text { Cold hands: } 1 \\
\text { Reduction in } \\
\text { blood pressure: } 1\end{array}$ \\
\hline Haider et al ${ }^{14}$ & 17 & 2 & 6 & $\begin{array}{l}\text { Gastrointestinal } \\
\text { upset: } 2 \\
\text { Intermittent } \\
\text { fatigue: } 1 \\
\text { Spitting: } 1 \\
\text { Shaking episodes } \\
\text { if dose missed: } 1\end{array}$ \\
\hline Holland et $a /^{31}$ & 3 & $1.25-2$ & 3 & Hypoglycaemia: 3 \\
\hline Abott et $a /^{32}$ & 3 & 1 & 3 & Diarrhoea: 3 \\
\hline Qin et $a l^{17}$ & 58 & $1-1.5$ & 58 & $\begin{array}{l}\text { Diarrhoea: } 37 \\
\text { Sleep change: } 18 \\
\text { Bradycardia: } 58\end{array}$ \\
\hline
\end{tabular}

RSV, respiratory syncytial virus.

revealed no significant cardiovascular morbidity. ${ }^{26}$ However, $4.3 \%$ (nine cases) of children in this study reported minor symptoms including lethargy, disorientation and wakefulness. ${ }^{26}$ Table 3 shows the side effects reported in studies on infantile haemangiomas. ${ }^{6} 814173132$ Diarrhoea has been reported in the literature in both adults and children on propranolol. ${ }^{17} 3233$ Three infants in one centre developed diarrhoea on $1 \mathrm{mg} / \mathrm{kg}$ of propranolol for infantile haemangiomas, with two improving on cessation of treatment. ${ }^{32}$ In another study in China almost two thirds of children (64\% 37/58) with infantile haemangiomas being treated with propranolol developed diarrhoea while on treatment. ${ }^{17}$ It has been suggested that the children were either more susceptible to propranolol than adults or alternatively, that the diarrhoea was secondary to maltitol in the propranolol suspension causing osmotic diarrhoea. ${ }^{32}$

Propranolol inhibits the sympathetic nervous system by blocking the $\beta$-receptors on the nerves of the sympathetic system as well as reducing cardiac contractility, thus causing bradycardia and reduced blood pressure, respectively. The majority of patients have no side effects from this mechanism, but a survey from multiple US poison centres found 8/378 children less than 7 years of age having had a $\beta$-blocker overdose had associated cardiovascular instability, some requiring intravenous medication and fluids. Of these eight children with symptoms, three had taken propranolol in doses ranging from 5 to $12 \mathrm{mg} / \mathrm{kg} /$ dose.$^{29}$ There is also some concern about its use in some large haemangiomas, that lowering the heart rate and contractility with propranolol may cause decompensated cardiac failure. ${ }^{31}$ Those with large haemangiomas should therefore be referred to a paediatric cardiologist before commencing propranolol. 
$\beta_{2}$ Adrenoreceptors are located in the lungs and so nonselective $\beta$-blockers such as propranolol act on the airways. This can cause bronchospasm which usually only occurs in patients with known reactive airways disease. In one study on infantile haemangiomas, a child developed wheezing 3 months after initiating propranolol but symptoms resolved after treatment was stopped. The wheezing was thought to be undiagnosed allergic asthma as the child had a history of atopic dermatitis and no concomitant infection. ${ }^{8}$ There have been reports of bronchospasm in adults with no asthma history being treated with propranolol. ${ }^{34}$ Theoretically, premature infants with chronic lung disease may be at more risk from bronchospasm from propranolol given their sensitive airways; however there is currently no evidence to support this hypothesis.

\section{CONCLUSIONS}

There is clear evidence that propranolol is an effective treatment for infantile haemangiomas. Propranolol has been used for a number of decades for cardiovascular disease in children with a reasonable safety profile. Steroids are associated with greater toxicity, including more serious side effects such as stunted growth, hypertension and hypertropic obstructive cardiomyopathy. Given the encouraging response rates and low risk of adverse events, many centres are now using propranolol as first line treatment for haemangiomas. ${ }^{35}$

There are some concerns that must be addressed if propranolol is going to become the mainstay treatment of haemangiomas. Firstly, propranolol should only be used in complicated haemangiomas. With the advent of easy access to information, there is pressure from families to use propranolol for children with simple haemangiomas, particularly for cosmetic reasons. This would not be justified given that the majority of these haemangiomas resolve spontaneously. Not only would the costs rise but children would be placed at unnecessary risk from the potential side effects of propranolol.

Secondly, further research on propranolol safety and efficacy needs to be carried out given its increased popularity, and indeed dose range studies are underway. At present many dermatologists are using propranolol as first line treatment despite there being no published studies showing that it is as effective as or better than steroids for infantile haemangiomas. This is especially true for those rapidly growing lesions found in cosmetically sensitive areas (eg, the nose). A couple of studies are underway comparing these steroids and propranolol, but until this data is available it would seem prudent to reserve propranolol as second line treatment. However, the indications for propranolol use may change with the results of these studies. For those centres which continue to use propranolol as first line therapy, emphasis must be on producing written guidance by all interested parties so that treatment can be given safely until such time there are acceptable protocols based on trial evidence.

\section{Competing interests None}

Provenance and peer review Not commissioned; externally peer reviewed.

\section{REFERENCES}

1. Drolet BA, Swanson EA, Frieden IJ. Infantile hemangiomas: an emerging health issue linked to an increased rate of low birth weight infants. J Pediatr 2008;153:712-15.

2. Bowers RE, Graham EA, Tomlinson KM. The natural history of the strawberry nevus. Arch Dermatol 1960;82:667-80.

3. Léauté-Labrèze $\mathbf{C}$, Taïeb $\mathbf{A}$. [Efficacy of beta-blockers in infantile capillary haemangiomas: the physiopathological significance and therapeutic consequences]. Ann Dermatol Venereol 2008;135:860-2.
4. Zimmermann AP, Wiegand S, Werner JA, et al. Propranolol therapy for infantile haemangiomas: review of the literature. Int J Pediatr Otorhinolaryngol 2010;74:338-42.

5. Schwartz RA, Sidor MI, Musumeci ML, et al. Infantile haemangiomas: a challenge in paediatric dermatology. J Eur Acad Dermatol Venereol 2010;24:631-8.

6. Buckmiller LM, Munson PD, Dyamenahalli U, et al. Propranolol for infantile hemangiomas: early experience at a tertiary vascular anomalies center. Laryngoscope 2010;120:676-81.

7. Léauté-Labrèze $\mathbf{C}$, Dumas de la Roque $\mathrm{E}$, Hubiche $\mathrm{T}$, et al. Propranolol for severe hemangiomas of infancy. N Eng/ J Med 2008;358:2649-51.

8. Sans V, de la Roque ED, Berge J, et al. Propranolol for severe infantile hemangiomas: follow-up report. Pediatrics 2009;124:e423-31.

9. Denoyelle F, Leboulanger N, Enjolras 0, et al. Role of Propranolol in the therapeutic strategy of infantile laryngotracheal hemangioma. Int J Pediatr Otorhinolaryngol 2009;73:1168-72

10. Rosbe KW, Suh KY, Meyer AK, et al. Propranolol in the management of airway infantile hemangiomas. Arch Otolaryngol Head Neck Surg 2010;136:658-65.

11. Marsciani A, Pericoli R, Alaggio R, et al. Massive response of severe infantile hepatic hemangioma to propanolol. Pediatr Blood Cancer 2010;54:176.

12. Li YC, McCahon E, Rowe NA, et al. Successful treatment of infantile haemangiomas of the orbit with propranolol. Clin Experiment Ophthalmol 2010;38:554-9.

13. Manunza F, Syed S, Laguda B, et al. Propranolol for complicated infantile haemangiomas: a case series of 30 infants. Br J Dermatol 2010;162:466-8.

14. Haider KM, Plager DA, Neely DE, et al. Outpatient treatment of periocular infantile hemangiomas with oral propranolol. J AAPOS 2010;14:251-6.

15. Maturo S, Hartnick C. Initial experience using propranolol as the sole treatment for infantile airway hemangiomas. Int J Pediatr Otorhinolaryngol 2010;74:323-5.

16. Naouri M, Schill T, Maruani A, et al. Successful treatment of ulcerated haemangioma with propranolol. J Eur Acad Dermatol Venereol 2010;24:1109-12.

17. Qin ZP, Liu XJ, Li KL, et al. [Treatment of infantile hemangiomas with low-dose propranolol: evaluation of short-term efficacy and safety]. Zhonghua Yi Xue Za Zhi 2009;89:3130-4

18. Wax PM, Erdman AR, Chyka PA, et al. beta-blocker ingestion: an evidencebased consensus guideline for out-of-hospital management. Clin Toxicol (Phila) 2005;43:131-46.

19. Paediatric Formulary Committee. BNF for Children [5th edition]. London: BMJ Publishing Group, Pharmaceutical Press, and RCPCH Publications; 2009.

20. Lawley LP, Siegfried E, Todd JL. Propranolol treatment for hemangioma of infancy: risks and recommendations. Pediatr Dermatol 2009;26:610-14.

21. laccarino $\mathbf{G}$, Ciccarelli $M$, Sorriento $D$, et al. Ischemic neoangiogenesis enhanced by beta2-adrenergic receptor overexpression: a novel role for the endothelial adrenergic system. Circ Res 2005;97:1182-9.

22. Storch $\mathbf{C H}$, Hoeger PH. Propranolol for infantile haemangiomas: insights into the molecular mechanisms of action. Br J Dermato/ 2010;163:269-74.

23. Fredriksson JM, Lindquist JM, Bronnikov GE, et al. Norepinephrine induces vascular endothelial growth factor gene expression in brown adipocytes through a beta -adrenoreceptor/cAMP/protein kinase A pathway involving Src but independently of Erk1/2. J Biol Chem 2000;275:13802-11.

24. Zhang D, Ma Q, Shen S, et al. Inhibition of pancreatic cancer cell proliferation by propranolol occurs through apoptosis induction: the study of betaadrenoceptor antagonist's anticancer effect in pancreatic cancer cell. Pancreas 2009;38:94-100

25. Kuperman S, Stewart MA. Use of propranolol to decrease aggressive outbursts in younger patients. Open study reveals potentially favorable outcome. Psychosomatics 1987;28:315-19.

26. Love JN, Howell JM, Klein-Schwartz W, et al. Lack of toxicity from pediatric beta-blocker exposures. Hum Exp Toxicol 2006;25:341-6.

27. Love JN, Sikka N. Are 1-2 tablets dangerous? Beta-blocker exposure in toddlers. J Emerg Med 2004;26:309-14.

28. Kallen RJ, Mohler JH, Lin HL. Hypoglycemia: a complication of treatment of hypertension with propranolol. Clin Pediatr (Phila) 1980;19:567-8.

29. Belson MG, Sullivan K, Geller RJ. Beta-adrenergic antagonist exposures in children. Vet Hum Toxicol 2001;43:361-5.

30. Breur JM, de Graaf M, Breugeum CC, et al. Hypoglycemia as a result of propranolol during treatment of infantile hemangioma: a case report. Pediatr Dermatol. 2011;28:169-71.

31. Holland KE, Frieden IJ, Frommelt PC, et al. Hypoglycemia in children taking propranolol for the treatment of infantile hemangioma. Arch Dermatol 2010:146:775-8.

32. Abbott J, Parulekar M, Shahidullah H, et al. Diarrhea associated with propranolol treatment for hemangioma of infancy (HOI). Pediatr Dermatol 2010;27:558.

33. Horvath F, Jr, Marbury TC, Uhlemann ER, et al. Severe diarrhea secondary to propranolol. South Med J 1979;72:367-8.

34. Fraley DS, Bruns FJ, Segel DP, et al. Propranolol-related bronchospasm in patients without history of asthma. South Med J 1980;73:238-40.

35. Holmes WJ, Mishra A, Gorst C, et al. Propranolol as first-line treatment for infantile hemangiomas. Plast Reconstr Surg 2010;125:420-1. 